\title{
15: 79262255-79392157
}

National Cancer Institute

\section{Source}

National Cancer Institute. 15: 79262255-79392157. NCI Thesaurus. Code C45026.

Physical location of IL16_Gene 